\title{
THE COURTS AND THE CONGRESS: SHOULD JUDGES DISDAIN POLITICAL HISTORY?
}

\author{
Peter L. Strauss*
}

\begin{abstract}
In an earlier article in these pages, Professor John Manning argued that the use of legislative materials by courts in effect permits Congress to engage in delegation of its authority to subunits of the legislature, in violation of the separation of powers. Professor Strauss, acknowledging that the previous generation of courts may have excessively credited the minutiae of legislative history, responds that judicial attention to the political history of legislation is required, not forbidden, by considerations of constitutional structure. Only awareness of that history will promote interpretation reflective of the context and political moment of Congress's action. Our history of previous conflicts between legislature and judiciary ought to have demonstrated the hazards of a judiciary that holds itself aloof from the legislative enterprise. Both long traditions of the common law and constitutional allocations of authority counsel judges to interpret statutes with a view to adding "force and life" to the remedies legislatures adopt. Professor Strauss acknowledges that, for the reasons Professor Manning evoked, courts should not accord legal authority to individual elements of legislative history. Nonetheless, he argues, the use of political history to inform the judge's own interpretation fits comfortably within a broad range of judicial practice; and pointedly ignoring political history risks releasing the courts from separation of powers constraints equally important to their own functioning. An intelligent, independent, and respectful attention to political history need reflect neither judicial subservience to the legislature nor, what would be as objectionable, judicial disdain for its work.
\end{abstract}

\section{INTRODUCTION}

My colleague John Manning's recent article in these pages, "Textualism As a Nondelegation Doctrine," 1 is typically insightful and persuasive. Once members of Congress became aware that judges would rely on legislative history, he observes, they began using it to do what they could not accomplish by statutory text. This effect was compounded by the enthusiasm judges showed for the practice. If congressional awareness that interpreters would refer to legislative history could encourage its production in any case, some judicial statements made in the years following the judicial crisis of the 1930s seemed to accord it authority-in-fact. This judicial reliance, he argues, resulted in legislative arrangements for making important judgments by fractions of the Congress rather than by "two houses plus presentment." In this way, the use of legislative history effected a delegation within the legislative branch. As Professor Manning

* Betts Professor of Law, Columbia University School of Law. My thanks to Kent Greenawalt, John Manning, Joseph Raz, and Jeremy Waldron, who read and commented helpfully on earlier drafts.

1. 97 Colum. L. Rev. 673 (1997). 
would concede, of course, no formal delegation has occurred; ${ }^{2}$ statutory interpretation remains an irreducibly judicial (or administrative) act, whose outcome the legislative history can do no more than influence. Yet the effect on congressional practice, he contends, both ought to alarm us as a violation of separation of powers principles and argues strongly for an intelligent textualism in interpreting statutes. Textualism is now revealed as not merely wise, but also constitutionally compelled.

What ought to give us pause about the analysis, this brief Essay is intended to suggest, is its failure to give equal attention to the nature of judges and judging, to the impact on judicial behaviors of freedom from any obligation to respect political history. ${ }^{3}$ Judicial willingness to learn from and respect the political history of legislation, these pages argue, is a necessary element of appropriate legislative-judicial relationships. The argument, admittedly impressionistic, is presented under four heads: first, that the conditions of legislative-judicial conversation require that legislative speech be understood as the product of a context; second, that previous experience with struggles between a textualist judiciary and legislatures ought to have convinced us of the hazards of a textualist approach; third, that techniques for giving political history persuasive (not controlling) force comfortably fit judicial practice generally and help to meet problems otherwise created by the necessary politicality of certiorari review; and, finally, that a judicial commitment to regarding legislation as purposive (with concomitant attention to its political history) is, in itself, a constituent part of the separation of powers. Our courts have generally acknowledged their stake in governance and consequent responsibility for partnership with the legislature. Although we expect of them the effort to abstract their own political preferences from the judgments they reach, judges are no more capable than any of us of living outside the contemporary social context, indifferent to its pulls and pushes. What the history of judicial action in our country-the earlier episode of judicial formalism that produced the realist insight—ought to have taught us, and what Professor Manning does not sufficiently address, is that textualism facilitates the judicial pursuit of political agendas; it heightens the risks of legislative-judicial confrontations and of outcomes inconsistent with the idea of partnership.

\section{The Conditions of Dialog}

In 1839, reflecting on the experience of the British Parliament in dealing with the interpretive styles of the English courts, Francis Lieber, one of the great early American legal scholars, evoked the homely meta-

2. Cf. Loving v. United States, 116 S. Ct. 1737, 1752-53 (1996) (Scalia, J., concurring).

3. As will amply appear below, this Essay does not claim that it is useful to employ bits and pieces of legislative reports or debates to resolve particular issues of meaning. In referring to "political" rather than "legislative" history, I hope to make clear that my concern is with fostering judicial awareness of what problems concerned Congress and what was the general thrust of its response. 
phor of a housekeeper giving orders to her servant to argue for the necessity of the servant's effort to understand his employer's language in context. ${ }^{4}$ His point was that interpretation was not only inevitable, but also depended upon the good faith of the interpreter in attempting to understand the instructions she was being given.

The British spirit of civil liberty, induced the English judges to adhere strictly to the law, to its exact expressions. This again induced the law-makers to be, in their phraseology, as explicit and minute as possible, which causes such a tautology and endless repetition in the statutes of that country, that even so eminent a statesman as Sir Robert Peel, declared in parliament, that he "contemplates no task with so much distaste, as the reading through an ordinary act of parliament." Men have at length found out, that little or nothing is gained by attempting to speak with absolute clearness, and endless specifications, but that human speech is the clearer, the less we endeavor to supply by words and specifications, that interpretation which common sense must give to human words. However minutely we may define, somewhere we needs must trust at last to common sense and good faith. ${ }^{5}$

If we imagine a legislature with the best of will adopting statutory instructions, we know at once that as a human institution it will be imperfectly foresightful, unaware of all possible meanings the words it chooses could be given, and solipsistic. More important, even the best of judiciar-

4. Suppose a housekeeper says to a domestic: "fetch some soupmeat," accompanying the act with giving some money to the latter. The domestic will be unable to execute the order without interpretation, however easy, and, consequently, rapid the performance of the process may be. Common sense and good faith tell the domestic, that the housekeeper's meaning was this: 1 . He should go immediately, or as soon as his other occupations are finished; or, if he is directed to go in the evening, that he should go the next day at the usual hour; 2. that the money handed him by the housekeeper is intended to pay for the meat thus ordered, and not as a present to him; 3. that he should buy such meat and of such parts of the animal, as, to his knowledge, has commonly been used in the house he stays at, for making soups; 4 . that he buy the best meat he can obtain, for a fair price; 5 . that he go to that butcher who usually provides the family with whom the domestic resides, with meat, or to some convenient stall, and not to any unnecessarily distant place; 6 . that he return the rest of the money; 7 . that he bring home the meat in good faith, neither adding any thing disagreeable nor injurious; 8 . that he fetch the meat for the use of the family and not for himself. Suppose, on the other hand, the housekeeper, afraid of being misunderstood, had mentioned these eight specifications, she would not have obtained her object, if it were to exclude all possibility of misunderstanding. For, the various specifications would have required new ones. Where would be the end? We are constrained then, always, to leave a considerable part of our meaning to be found out by interpretation, which, in many cases must necessarily cause greater or less obscurity with regard to the exact meaning, which our words were intended to convey.

Francis Lieber, Legal and Political Hermeneutics 28-30 (Neil H. Alford, Jr. et al. eds., The Legal Classics Library 1994) (1839).

5. Id. at $30-31$. 
ies can be no less human an institution. As Fish (among others) has persuasively shown, ${ }^{6}$ once one acknowledges the subjectivity and imprecision of language, one has necessarily acknowledged it for everyone-the interpreter as well as the interpreted. The same proposition applies if we decide to use a theoretical framework, say "public choice," that puts the public-regarding nature of legislative action in doubt; if we are going to be concerned that the legislature may not act with the best of will, we must be prepared to ask similar questions about judges. ${ }^{7}$ There is no way of placing some people or institutions outside of perspectives like these, which rest on universal propositions about human behavior. All this should make us cautious about proposing principles of interpretation that both devalue knowing the context within which the legislature has spoken and assume away the possibilities of willfulness on the part of the interpreter.

Professor Manning acknowledges the force of Lieber's observations, ${ }^{8}$ as he does the appropriateness of a legislator's assumption that later interpreters of his words will assume they connote "what one would be normally understood as saying, given the circumstances in which one said it."'9 The instinctive, natural quality of referring to such materials in the course of interpretation-and the artificiality of refusing to do so when they happen to arise in Congress-was well illustrated in a pair of unanimous decisions issued by the Supreme Court on December 2, 1997. The exact details of the cases need not concern us here. In Salinas $v$. United States, one issue was the meaning of a federal conspiracy statute. ${ }^{10}$ Justice Kennedy's opinion for the Court, subscribed by all members, included the following passage:

Our recitation of conspiracy law comports with contemporary understanding. When Congress passed RICO in 1970, see Pub. L. 91-452, $\$ 901$ (a), 84 Stat. 941, the American Law Institute's Model Penal Code permitted a person to be convicted of conspiracy so long as he "agrees with such other person or persons that they or one or more of them will engage in conduct that constitutes such crime." American Law Institute, Model Penal Code $\$ 5.0391$ ) (a) (1962). As the drafters emphasized, "so long as the purpose of the agreement is to facilitate commission of a crime, the actor need not agree 'to commit' the crime." American Law Institute, Model Penal Code, Tent. Draft No. 10, p. 117 (1960). The Model Penal Code still uses this formulation. ${ }^{11}$

6. See Stanley E. Fish, Force, 45 Wash. \& Lee L. Rev. 883, 885-87 (1988); Stanley E. Fish, Not of an Age, But for All Time: Canons and Postmodernism, 43 J. Legal Educ. 11, 19-20 (1993).

7. See Einer R. Elhauge, Does Interest Group Theory Justify More Intrusive Judicial Review?, 101 Yale L.J. 31 (1991).

8. See Manning, supra note 1 , at 728-29.

9. Id. at 692, quoting Joseph Raz, Intention in Interpretation, in The Autonomy of Law 249, 268 (Robert P. George ed., 1996).

10. 118 S. Ct. 469,472 (1997).

11. Id. at 477 . 
In Foster $v$. Love, the issue concerned the meaning of a Nineteenth Century congressional statute regulating elections to federal office. ${ }^{12}$ Justice Souter's opinion for the Court was joined by all his colleagues for most purposes, but Justice Kennedy (and also Justices Scalia and Thomas) did not join in one paragraph of the opinion; that paragraph "buttressed" the Court's judgment by referring to

an appreciation of Congress's object "to remedy more than one evil arising from the election of members of Congress occurring at different times in the different States." Ex parte Yarbrough, 110 U.S. 651, 661 (1884). As the sponsor of the original bill put it, Congress was concerned both with the distortion of the voting process threatened when the results of an early federal election in one State can influence later voting in other States, and with the burden on citizens forced to turn out on two different election days to make final selections of federal officers in presidential election years . . . [quoting the sponsor's language]. ${ }^{13}$

It is indeed striking that Justice Kennedy, who found the views of the Model Penal Code's drafters helpful in understanding what that widely used and respected legislation should be understood to provide, felt obliged to dissent from the mention of the drafter's views of the statute in Foster. The help such expressions give in understanding "the circumstances in which one said it" seem if anything the more relevant, when the issue is interpreting Nineteenth Century expressions.

\section{Progressive Congress, Formalist Courts}

One can find common law courts attending to legislative purposes at least as far back as Lord Coke's decision in Heydon's Case, ${ }^{14}$ which is extensively discussed below. ${ }^{15}$ Political history came into judicial use as an interpretive aid in American courts before the turn of the century, more or less simultaneously with the increased pace of legislation that accompanied the Progressive Era. ${ }^{16}$ Judicial use of political history generally appeared then on one side of the notorious struggle, identified with the adoption of legislative measures for protecting workers, over the interplay of legislative and judicial lawmaking powers and the question which power would dominate in a system of both statutory and common law authority. ${ }^{17}$ With increasing frequency, legislatures were passing statutes that challenged the comfortable structures of the common law. As part

12. 118 S. Ct. 464,466 (1997).

13. Id. at 468 .

14. 76 Eng. Rep. 637 (K.B. 1584).

15. See infra Part IV.

16. The history of its use is recounted, with an extensive critical and theoretical analysis, in William N. Eskridge, Jr., Legislative History Values, 66 Chi.-Kent L. Rev. 365 (1990).

17. Lochner v. New York, 198 U.S. 45 (1905), is the usual symbol of judicial resistance to Progressivism. In the nonconstitutional context of statutory interpretation, however, the battles were often fought over issues of remedy for workplace injury. See, e.g., Louis L. 
of the struggle over the nature of law, that Holmes captured in his dismissive reference to a "brooding omnipresence in the sky," 18 the Formalist School of judging responded to these statutes with defensiveness about "derogation of the common law" and protection of its elegant intellectual structures. ${ }^{19}$ The result was an extended period of legislative-judicial struggle, with judges reluctantly giving ground to the persistent winds of legislative change. Judges we usually place in the pantheon of the greats-Holmes, Brandeis, Cardozo, Stone, and Hand-were among those who found political history useful in understanding and respecting the directions in which those winds were blowing.

These judges insisted that legislative judgments were to be uncovered, honored, even improvised upon. ${ }^{20}$ For them, it may be suggested, this understanding carried with it the proposition that-even in a common-law world accepting of a judicial role in lawmaking - their constitutional responsibility was to effectuate legislators' political judgments and to give these judgments priority over their own. The perception was built, and eventually prevailed, that the formalists had asserted an inappropriate political stance for judges, however camouflaged in the pretensions of omnipresent verities in the sky. Judges' proper responsibility, rather, was working out how legislatures were responding to contemporary problems. ${ }^{21}$ In that context even one who, like Holmes, professed in private writings the thought that " $[\mathrm{w}] \mathrm{e}$ do not inquire what the legislature meant; we ask only what the statute means,"22 might rely on legislative history to understand the context that gave the statute meaning. ${ }^{23}$ That

Jaffe \& Nathaniel L. Nathanson, Administrative Law: Cases and Materials 133-36 (2d ed. 1961).

18. Southern Pac. Co. v. Jensen, 244 U.S. 205, 222 (1917) (Holmes, J., dissenting).

19. For the Legal Process school, Johnson v. Southern Pac. Co., 117 F. 462 (8th Cir. 1902), rev'd, 196 U.S. 1 (1904), holding that locomotives need not be equipped with the automatic couplers statutorily required for railroad "cars," provided the classic example of formalism. See Henry M. Hart, Jr. \& Albert M. Sacks, The Legal Process 1133 (William N. Eskridge \& Philip P. Frickey eds., 1994).

20. See, e.g., International Stevedoring Co. v. Haverty, 272 U.S. 50, 50-52 (1926) (Holmes, J.) (unusually broad interpretation of "seaman" informed by legislative directions vis à vis the common law); Panama R.R. Co. v. Rock, 266 U.S. 209 (1924) (Holmes, J., dissenting) (inferring common law rule from common legislative practice); cf. infra text accompanying note 83 (quoting Roscoe Pound).

21. See, e.g., Arizona Employers' Liab. Cases, 250 U.S. 400, 433 (1919) (Holmes, J., concurring).

The legislature may have reasoned thus.... It is reasonable that the public should pay the whole cost of producing what it wants and a part of that cost is the pain and mutilation incident to production. By throwing that loss upon the employer in the first instance we throw it upon the public in the long run and that is just. If a legislature should reason in this way and act accordingly it seems to me that it is within constitutional bounds.

Id.

22. Oliver W. Holmes, The Theory of Legal Interpretation, 12 Harv. L. Rev. 417, 419 (1899), reprinted in Collected Legal Papers 207 (1920).

23. Professor Eskridge, making this point, remarks that: 
followed from judges' obligation to accept the solutions legislatures might choose whether or not they would be their own, and to build upon those solutions in the continuing work of shaping the law. On this view, the course that statutes had taken while passing through the legislature provided useful data. As in Europe at about the same time, ${ }^{24}$ these judges' attention to the political history of legislation reflected their acceptance that formal analysis could not suffice to adumbrate what were political judgments of the community as a whole.

The New Deal's dramatic shifts in constitutional and statutory interpretation were only the resolving crisis in this struggle. With the rejection of "substantive due process" arguments about freedom of contract, and the concomitant recognition of legislative supremacy in economic regulation, came particularly strong statements about the value of legislative history. Minute attention to the details of legislative history, one might even speculate, was among the means by which the postcrisis judiciary voiced recognition of its predecessors' earlier error. ${ }^{25}$ It assured the Congress and the people that judges now accepted and understood that statutes are primary and that law's legitimacy derives from politics, not formal reasoning from abstract premises. That a Douglas or even a Frankfurter may have taken his insights a step too far in effecting judicial retreat from the hubris of earlier times, ${ }^{26}$ however, ought not mislead us into seeing attention to the political context of legislation as a phenomenon particular to the New Deal. Experience, history, political judgment-not only logic in relation to "objective" meaning-had characterized the approaches of the great judges of the Progressive era.

[Holmes's] opinion for the Court in Boston Sand \& Gravel Co. v. United States, 278 U.S. 41 (1928), for example, relied on legislative history to interpret a statute the dissenting Justices found clear on its face. "It is said that when the meaning of language is plain we are not to resort to [extrinsic] evidence in order to raise doubts. That is rather an axiom of experience than a rule of law," Holmes responded, "and does not preclude consideration of persuasive evidence if it exists." Id. at 48.

See Eskridge, supra note 16, at 388 n.87.

24. The leading European analysis was Francois Geny, Méthode d'Interprétation et Sources en Droit Privé Positif (1899).

25. See United States v. American Trucking Ass'ns, 310 U.S. 534 (1940), long taken to reflect the "victory" of legislative history proponents over the "plain meaning" rule. See Arthur W. Murphy, Old Maxims Never Die: The "Plain-Meaning Rule" and Statutory Interpretation in the "Modern" Federal Courts, 75 Colum. L. Rev. 1299, 1301 (1975). The Court divided 5-4, with the Justices in the majority having a total of 10 years' experience on the Court; the Justices in dissent, 65.

26. The plurality opinion of Justice Douglas and dissent of Justice Frankfurter in Schwegmann Bros. v. Calvert Distillers Corp., 341 U.S. 384 (1951), are characteristic in their exacting attention to the details of legislative consideration and apparent search for particularly intended meaning, reflecting "the respect we have accorded authoritative legislative history in scores of cases during the last decade." Id. at 399 (Frankfurter, J., dissenting). 


\section{Uncertain Meaning and Political Context}

One of the genuinely attractive elements of Professor Manning's analysis is that he acknowledges both the necessity of consultations outside the text to find the context that animates effective interpretation, and the consequent difficulties posed by distinguishing between external sources that are, and are not, congressional in origin. ${ }^{27} \mathrm{He}$ urges us to distinguish between the use of dictionaries and prior judicial opinions, on the one hand, and legislative materials, on the other, because of the "very fact of congressional involvement" in creation of the latter. ${ }^{28}$ While, as he concedes, that fact makes more rational the supposition that the drafters were aware of the legislative materials-that they actually reflect an influential context-he argues that rules of judicial decision giving those materials "decisive" or "authoritative" status permit Congress to structure its own affairs to avoid the constitutionally required elements of bicameralism and presentment. This, he argues, is an invitation to laziness, to evasion of responsibility, to hidden law made by persons (committee members and/or staff) not authorized to do so. Here is a problem not presented when judges rely on other extrinsic factors, such as period dictionaries. To be sure, requiring Congress to anticipate the ways in which its words will be interpreted by judges or administrators or to predict how future readers will think its usage would have been understood, may diminish the accuracy of interpretive understanding in particular cases. Yet in the long run, he argues, these practices will benefit, not harm, the way in which Congress legislates.

The force of Professor Manning's argument is suggested by the following. Suppose that Congress, having read the Supreme Court's very surprising language in Stinson v. United States, ${ }^{29}$ were to enact the following statute: "Commentary in a House or Senate Report that interprets or explains a statutory provision is authoritative unless it violates the Constitution or a federal statute, or is inconsistent with, or a plainly erroneous reading of, that statute." 30 Such a statute, purporting to require the courts to give legal force to events in the course of legislative development that were not bicamerally approved and presented, would dramatically illustrate Professor Manning's point. Even were a court to adopt this rule for its own convenience, without even a hint of congressional compulsion, his analysis shows us the difficulty engendered for future congressional behavior (as well as the lack of interpretive sense). Manning is

27. See, e.g., Manning, supra note 1, at $695,725$.

28. Id. at 706 .

29. 508 U.S. 36 (1993).

30. Compare id. at 38: "[C]ommentary in the [United States Sentencing Commission's] Guidelines Manual that interprets or explains a guideline is authoritative unless it violates the Constitution or a federal statute, or is inconsistent with, or a plainly erroneous reading of, that guideline." 
convincing that the Stinson approach has no place in the world of statutes. ${ }^{31}$

If, as at times the argument hints, ${ }^{32}$ Professor Manning means only to say that it is inappropriate for courts to regard themselves as bound in any legal sense by words spoken or written during Congress's consideration of legislation, his case is easily made. As we have known since Marbury, it is the constitutional duty and authority of the courts "to say what the law is." ${ }^{33}$ Formal authority to interpret is in the courts. If judges pay attention to legislative history as a matter of self-imposed discipline, as a means of keeping themselves within an interpretational role, their doing so does not in formal terms raise any delegation problems of the character Professor Manning describes. It is the judges who are interpreting; they are deciding, for themselves, how much authority to accord what they find. When it enacts a statute, Congress takes its chances how that law will be interpreted. It does not and cannot limit the possible outcomes by any means other than the words it enacts.

The problem arises when one moves from the proposition that courts are not bound by legislative history (and indeed have erred to the extent any have suggested otherwise), to the conclusion that it is usually inappropriate for them even to look to those materials for help in understanding and resolving an interpretive problem that may be before them. In analogous situations, judges have long known how to take an intermediate stance. Thus, in deciding how to assess agency interpretations of statutory language, courts clearly distinguish between cases in which they are "bound" by an agency's view and others in which they may find the agency's view influential in exercising their own undoubted authority. In $N L R B$ v. Hearst, for example, the Supreme Court famously and controversially found Congress had delegated to an administrative agency the job (within reasonable, court-determined limits) of giving meaning to the statutory term "employee." ${ }^{4}$ In that instance (as in the more recent

31. This is not the place to discuss the legitimacy of the Stinson approach in the world of sentencing guidelines-although we might understand in practical terms why the Court would prefer not to be burdened with interpretation of those guidelines and believe that interpretations generated by the administrative process of an agency "in the Judicial Branch," see Mistretta v. United States, 488 U.S. 361, 395-96 (1989), could generate uniformity at low institutional cost. Professor Manning's suggestion, see Manning, supra note 1, at 729-30, that Congress could accomplish similar ends by enacting its legislative history satisfies only formally. As with omnibus legislation, cf. Sorenson v. Secretary of the Treasury, 475 U.S. 851, 866-67 (1986) (Stevens, J., dissenting), it is unrealistic to believe that such a course would reflect congressional consideration in fact. Nor is it hard to imagine, if one accepts the perspectives on congressional behaviors sometimes expressed in his analysis, that Congress would find it in its interest routinely to defeat his analysis by this formal means, if it could.

32. See, e.g., Manning, supra note 1, at 737 n.272.

33. Marbury v. Madison, 5 U.S. (1 Cranch) 137, 177 (1803).

34. 322 U.S. 111, 131-32 (1944). 
Chevron decision), ${ }^{35}$ one could characterize the courts as "bound" by the agency's reasonable decision; interpretive authority had, to a degree the courts themselves determined, been delegated to the agency. For years before Hearst, however, the Court had been indicating that administrative readings of statutes should be given weight by judges in interpretation, because of the agencies' awareness of the circumstances of drafting and their (politically supervised) responsibilities for placing statutes into implementation - that is to say, the political context of legislation. ${ }^{36}$ The force of the agency views, here, was not binding but influential-constituting weights on scales whose balancing was a judicial responsibility. In the same year as Hearst, in Skidmore v. Swift $\mathcal{F}^{\circ}$ Co., the Court illustrated the force of that middle ground in an oft-reiterated passage that Professor Manning quotes:

We consider that the rulings, interpretations and opinions of the Administrator under this Act, while not controlling upon the courts by reason of their authority, do constitute a body of experience and informed judgment to which courts and litigants may properly resort for guidance. The weight of such a judgment in a particular case will depend upon the thoroughness evident in its consideration, the validity of its reasoning, its consistency with earlier and later pronouncements, and all those factors which give it power to persuade, if lacking power to control. ${ }^{37}$

Courts, having full authority to interpret the statutes, thus could find the political history of a statute persuasive about the result they should reach without being bound by it. Professor Manning acknowledges the possibility of this middle course; however, he would permit courts to take it "only after a full and independent verification of the accuracy and persuasiveness of its contents"38 - that is, only if evidence from outside the legislative history, as such, pointed in the same direction. His assertion appears to be that the risk political history will be "contrived" 39 makes it otherwise doubtful for judges to look to legislative materials even for possible guidance of what is unambiguously their own judgment. Professor Manning's acknowledgment is an important one, reflecting the moderation of his textualism. The fear of congressional manipulation seemingly reflected in the independent verification requirement he would impose-in my judgment, an unsustainable attitude for courts to take to-

35. See Chevron, U.S.A., Inc. v. Natural Resources Defense Council, Inc., 467 U.S. 837

(1984). Chevron is discussed infra at text accompanying notes 41-43.

36. See, e.g., United States v. American Trucking Ass'ns, 310 U.S. 534 (1940); Norwegian Nitrogen Prod. Co. v. United States, 288 U.S. 294 (1933). The argument is further developed in Peter L. Strauss, When the Judge is not the Primary Official with Responsibility to Read: Agency Interpretation and the Problem of Legislative History, 66 Chi.-Kent L. Rev. 321 (1992).

37. 323 U.S. 134, 140 (1994) (quoted in Manning, supra note 1, at 733 n.252).

38. Manning, supra note 1 , at 733 .

39. See id. at $735,737$. 
wards legislatures and their work-reflects the narrow, and yet possibly profound, distance between us.

The reasons we should often prefer for judges to consult these materials, in my judgment, derive from the inherent limits to legislative precision, the superior political claim of the legislature to act, and the risks we face from judicial as well as legislative adventurism. While, on the whole, humans communicate with one another with a large measure of success, Lieber was surely correct in remarking that this success depends both on shared conventions about meaning and expectations of good faith in dialog. ${ }^{40}$ Language is imprecise and manipulable. Often we can do no better than identify a possible range of meanings a particular expression evokes. Such difficulties seem particularly likely to be present in the kinds of cases where parties undertake the risks and expense of litigation over issues of meaning and then pursue the matter to superior courts. Judges in such cases cannot be expected to fool themselvesalthough they might try to fool us-that particular results are ones any properly instructed reasoner, say a cleverly instructed computer, would reach.

Identifying possible outcomes and selecting a particular outcome are distinct tasks. This proposition underlay the Supreme Court's protean Cheuron, Inc. v. Natural Resources Defense Council, ${ }^{41}$ in which the Court identified as a first, unmistakably judicial step deciding whether Congress had resolved the statutory issue before it - that is, what meanings a statute could possibly have-but characterized the authority reasonably to choose a particular outcome from among those available, as having been delegated to the responsible agency. ${ }^{42}$ The second-step judgment, the Court recognized, was one of policy. ${ }^{43}$ For courts also, one can believe that the first step of identifying possible meaning is "objective" in a way that the second, choosing among those possibilities, is not. The first step is strongly language-centered. Although we can imagine circumstances in which knowing the political context of enactment would help us to identify possibilities of statutory meaning that otherwise would not occur to us, the underlying question remains what the statute could mean. The possible responses to this question are, definitionally, set by its language, as it could be understood.

Once we have identified a range of possible meanings, however, we are outside the realm where language alone can answer the question of meaning for us. Why would we prefer a judge operating within such a range to be indifferent or oblivious to information about the political history of that legislation? To have set the problem up in this way is to have underscored that it is the judge's discretion that will be exercised-whatever extrinsic evidence she uses. If, however, the judge is act-

40. See supra text accompanying notes 4-5.

41. 467 U.S. 837 (1984).

42. See id. at $842-44$.

43. See id. at 864-66. 
ing on the hypothesis that she is, in some sense, the legislature's agent in making that decision, her awareness of the political history of the statute being interpreted makes it more, rather than less likely that her decision will satisfy that relationship.

Imagined in this way, knowledge of the political history of legislation serves the same function as knowledge how a government agency responsible for drafting legislation has interpreted it, ${ }^{44}$ or how an agency with responsibility to implement a new statute has done so. ${ }^{45}$ Information of this character moderates risks created by inevitable characteristics of judicial interpretation that can render it destabilizing: Such interpretation may not be required until years after the legislative moment, when both governmental agencies and private parties will have arranged their affairs in accordance with their understanding of the statutory scheme. ${ }^{46}$ Moreover, judges resolve discrete disputes. Even apart from the distorting lens that the vagaries of litigation interpose between a statute and a judge's vision, it will be hard for judges (who lack continuing responsibilities for a particular program) to see a complex statute as an integrated whole, or to grasp meanings that may be quite firmly settled in the public and private communities that deal with the statute on a daily and intimate basis. Protecting settled expectations about meaning in the relevant communities, like treating the legislature as a partner in the work of government, builds the general social sense of order. Knowledge of the political history of legislation and a disposition to be informed by it (in what are unmistakably the judiciary's own judgments) makes of the judiciary a more reliable partner, a more readily trusted agent. The work of government goes more smoothly if the legislature does not have to fear that, unless it is elaborately precise indeed, it may be misunderstood. ${ }^{47}$

One way of expressing a concern, then, about judges putting aside the materials of political history is that doing so will reduce the resources available for interpretation. Moreover, it will do so in a way especially likely to reduce judicial access to understandings that will have come naturally to both the legislature and particularly affected communities. In another recent and thoughtful essay about the legislative history problem, Professor Thomas Merrill addressed these questions with striking effect:

Textualism, in contrast [to intentionalism], seems to transform statutory interpretation into a kind of exercise in judicial ingenuity. . . . The task is to assemble the various pieces of linguistic data, dictionary definitions, and canons into the best (most co-

44. See United States v. American Trucking Ass'ns, 310 U.S. 534, 545 (1940).

45. See Norwegian Nitrogen Prods. Co. v. United States, 288 U.S. 294, 305-08 (1933).

46. In Schwegmann Bros. v. Calvert Distillers Corp., 341 U.S. 384 (1951), for example, over a decade had passed since enactment of the statute in question, and both the federal agencies concerned (the Department of Justice and the Federal Trade Commission) and virtually all private actors concerned understood the statutory provision in question to have a particular meaning.

47. Compare the quotation from Lieber, supra note 4. 
herent, most explanatory) account of the meaning of the statute. This exercise places a great premium on cleverness ... [and] is subtly incompatible with an attitude of deference toward other institutions-whether the other institution is Congress or an administrative agency. In effect, the textualist interpreter does not find the meaning of the statute so much as construct the meaning. . . .

There are at least two reasons why textualism may lead to this more creative, less deferential style of judging. One [is that] textualism implicitly rejects the faithful agent model of judging that underlies intentionalism. . . .

The second reason is that the textualist must become creative out of necessity. ... . [A] Court that adopts the textualist method and rejects legislative history necessarily has fewer tools at its disposal to particularize the meaning of the text than was the case in the era of legislative history. Having fewer tools to work with, the textualist-like the painter working with a small palett [sic]-necessarily has to become more imaginative in resolving questions of statutory interpretation. ${ }^{48}$

Creativity, reduced deference, and the smaller palette all become magnified as sources of concern when one considers the policy-based, that is to say political, character of judicial choice among a set of possible meanings opened up by a statute's words. The issue has particular bearing in the Supreme Court, where the Court's certiorari jurisdiction underscores both its political role and the likelihood that a question of statutory meaning reaching it will be genuinely disputable. Courts who hear cases by necessity, as the product of a party's choice about whether to proceed or not, are not required to think of the cases they hear in political or strategic terms (although, of course, they might do so). A Court that constructs its own docket, however, selecting from thousands of applicants the relative handful that are "important to hear this Term," must inevitably think of them in that way. The initial focus of decision necessarily shifts from which party has better established its claim to prevail, to which expenditure of judicial resources will best serve the (judges' perception of) the national interest. Choosing what statutory questions to resolve-in what field to make law-may of course be influenced by factors independent of policy, such as whether the circuits are divided on the matter. But this is a decision that need not be, and is not, explained or justified. It is easy to suppose that the Justice exercising her discretion for or against certiorari will be moved by strategic and political considerations. "We granted leave to appeal," the New York Court of Appeals once remarked in an unguarded moment, "in order to take another step toward a complete solution of the problem partially cleared up in [two of our recent, prior cases]." 49 Whether or not often made so explicit, the

48. Thomas W. Merrill, Textualism and the Future of the Cheoron Doctrine, 72 Wash. U. L.Q. 351, 372-73 (1994).

49. Goldberg v. Kollsman Instrument Corp., 191 N.E.2d 81, 81 (N.Y. 1963). 
character and responsibilities of discretionary review jurisdiction make such an attitude inevitable. Making law, not deciding disputes, has become the defining characteristic of the job.

Even if it is the least dangerous branch, the judiciary as well as Congress is reached by concerns with "separation of powers," checks and balances, and the workability of government. It is easy to accept that ambition checking ambition is a constitutional good, and that one constitutional desideratum is the avoidance of rules that either permit Congress to evade its responsibility for legislation or arm its forays into zones of governance intended for others. Yet this is not the only principle at stake. Standard formulations of the doctrine governing "political questions" and judicial review, focusing now on the judicial role, incorporate principles of "respect due to a coordinate branch of the government" 50 that are hard to square with realpolitik concerns for possible legislative manipulations. On this view, the judiciary must avoid rules that intrude it into the work of the other branches, that conduce to endless warfare between them, that fail to capture the respect owing to another, coequal branch of government-that turn the courts' shared authority for making law into a power superior to Congress's, even beyond the constitutional realm. ${ }^{51}$

Rules for dealing with the work of another branch that require the judiciary to act in ignorance of the context of that work have just this effect. They are grounded in disdain for the internal procedures of a coordinate branch. They impose make-work on Congress, when the courts insist upon an interpretational palette that ostentatiously omits the colors of congressional process. They invite repetitive struggles that, even if not intended, are wasteful of the limited resources of time and effort Congress has available to it for its legislative agenda. ${ }^{52}$ They co-opt an agenda that is ordinarily set by the community problems Congress perceives through the lens of politics. Moreover, if it is appropriate to view congressional processes through the lens of public choice or other similar political theories, surely one must also bring similar focus to the judi-

50. Field v. Clark, 143 U.S. 649, 673 (1892), revoiced in Baker v. Carr, 369 U.S. 186, 217 (1962). In Field, the Court properly refused to rely upon legislative history to find whether a bill that had been presented to the President and signed by him was the same measure that had passed both Houses (it being alleged, with apparent support in the Congressional Record, that an actually enacted section had been omitted from the enrolled bill presented to him). If authority were needed to establish that legislative history does not have binding force, this seems particularly apt; here, though, the principal point is that-absent the need to enforce an explicit constitutional command-separation of powers principles forbid courts to adopt strategies of interpretation that embody disrespect for the procedures of a coordinate branch of government. Cf. United States v. Munoz-Flores, 495 U.S. 385, 391 n.4 (1990).

51. See Baker, 369 U.S. at 217.

52. The point has been dramatically illustrated by a number of recent running battles between the Supreme Court and Congress. See, e.g., West Virginia Univ. Hosp., Inc. v. Casey, 499 U.S. 83, 98-101 (1991) (Stevens, J., dissenting); Estate of Reynolds v. Martin, 985 F.2d 470, 475 n.2 (9th Cir. 1993). 
ciary. Once we begin to do so, we see the rich possibilities for the intentional infliction of such struggles in cases where Court and Congress disagree about the proper public policy to be followed.

Thus, resolution of the problem with which Professor Manning properly confronts us-that members of Congress observing judges, use of legislative materials have sought to take advantage of it in ways that have negative implications for Congress's own work-must in my judgment attend to judicial motivations, weaknesses, and excesses as well as legislative ones. The difficulty in doing so is raised precisely by the consideration that while Congress has the first chance with the words, judges have the last word in statutory interpretation..$^{53}$ This proposition, settled for us in Marbury, is underscored by the conclusion to which Manning's analysis unmistakably takes us, that Congress is powerless to prescribe interpretive rules for the courts that force them to recognize legislative history as authoritative. For just this reason, the courts can force Congress's attention to the judiciary's interpretive conventions. The principal weapon Congress has available in response-the one used early in this century to deal with courts that would not accept legislative judgments respecting labor policy ${ }^{54}$-is to appoint alternative interpreters who may employ other conventions. ${ }^{55}$ The judiciary's acceptance of their authority may have been the product of sound political sense, as well as a more theoretical understanding of what would be a desirable relationship between the two branches. But it is the confrontational battle itself that ought to have been avoided. A judicial effort to discern and be instructed by the politics of the enacting body would have, in addition to its evident risks, the virtue of referring preferences and politics to that body the public elects, and can hope to control, for the exercise of that function.

\section{Supportive Statutory Construction: The Lesson of HEYDON'S CASE}

Purposive interpretation traces its roots to Heydon's Case, which in 1584 identified four questions as having to be answered "for the sure and true interpretation of all statutes":

\section{As Jerry Mashaw writes:}

For law, this latter vision is profoundly unsettling. After all, the application of law relies on the authority of the text. If the text literally can mean anything, then the law is simply whatever the interpreter says it is. The legitimacy of the application of law will thus have to depend on some agreed methodology for giving meaning to legal texts. Otherwise, we are simply at the mercy of preferences or political ideology of the official interpreters. In such a world, democratic control of lawgiving and "government under law" might be only comforting myths, not everyday realities.

Jerry L. Mashaw, Greed, Chaos, and Governance: Using Public Choice to Improve Public Law 82 (1997).

54. See, e.g., Jaffe \& Nathanson, supra note 17, at 133-36.

55. See Strauss, supra note 36 , at 327-29. 
1st. What was the common law before the making of the Act.

2nd. What was the mischief and defect for which the common law did not provide.

3rd. What remedy the Parliament hath resolved and appointed to cure the disease of the commonwealth.

And 4th. The true reason of the remedy; and then the office of all the Judges is always to make such construction as shall suppress the mischief, and advance the remedy, and to suppress subtle inventions and evasions for continuance of the mischief, and pro privato commodo, and to add force and life to the cure and remedy, according to the true intent of the makers of the Act, pro bono publico. ${ }^{56}$

Today, when statutes are the dominant source of law, we should understand the first two questions as referring to "law," not "the common law." Thus, the first and second questions ask what was the law previously, and what mischief did it not provide for? This slight change suggests three propositions about the Heydon's Case questions that it will be useful to discuss in turn: First, if the second and third questions are intellectually distinct, only the third arguably raises delegation issues of the sort that concern Professor Manning. Second, the fourth Heydon's Case question embodies a normative commitment, that judges have an obligation to cooperate with the legislative impulse by using their common-law powers to propagate its force. Finally, both the inquiry as a whole, and the normative commitment embodied in its fourth element, assume what might be controversial, that legislation is purposive behavior.

\section{A. On Discerning "the Mischief and Defect"}

If it is reasonable to ask what was the problem to which a statute responded, surely any ordinary person making that inquiry would want to know what legislative consideration suggests. Hearings, debates, and reports will reveal what issues were brought to congressional attention, and what were not. Learned Hand made the point elegantly long ago, in a case involving the authority of the Securities and Exchange Commission to litigate independently of the Department of Justice. ${ }^{57}$ He quoted a passage from the testimony of a government witness who had proposed the language whose meaning was under discussion; since that language was adopted after the witness's explanation of the reason for wishing change, this court "cannot see how [anyone] can doubt what was the purpose of both committees in this amendment ... . There cannot be the least question that in fact it was at his suggestion that the change was made and that it was intended to allow the Commission complete autonomy in civil prosecutions." 58 Hand continued by denying that he was giving effect to legislative history as an interpretive matter:

56. 76 Eng. Rep. 637, 638 (K.B. 1584).

57. See SEC v. Robert Collier \& Co., 76 F.2d 939, 939 (2d Cir. 1935).

58. Id. at 940 . 
It would indeed be absurd to suppose that the testimony of a witness by itself could be used to interpret an act of Congress; we are not so using it. The bill was changed in a most significant way; we are concerned to learn why this was done; we find that it can most readily be explained, and indeed cannot naturally be explained on any other assumption than by supposing that the committees assented to a request from the very agency to whom the new functions were to be committed. To close our eyes to this patent and compelling argument would be the last measure of arid formalism. ${ }^{59}$

The issue here is understanding what social-legal problems were thought to require response. Considering the course of legislative development, to discover what kinds of problems were mentioned and what kinds were not, is the most natural means of accomplishing this understanding. This inquiry, properly regarded, is prelegal-an inquiry into the conditions generating legislative action, not the meaning of the action itself. For this reason, Professor Manning's delegation issue does not arise when the issue is identifying the mischief to which the legislature directed its action.

In a discussion of United States $v$. Fausto, ${ }^{60}$ towards the end of his article, Professor Manning acknowledges that legislative materials may have relevance for this kind of inquiry, but in a manner that reflects his dominant concern with the possibility that they may be "contrived by legislative agents to steer the course of judicial interpretation." ${ }^{1}$ Thus, for him, the court must be able to verify from external sources that the indications of the legislative history are accurate; a second case is sharply criticized for failing to make such an inquiry with sufficient assiduousness. ${ }^{62}$ There is in effect a presumption which must be overcome that the legislative process has been "contrived simply to produce an interpretive result preferred by a committee or sponsor." 63 Any such presumption would stand in sharp contrast to Judge Hand's acceptance of Congress's performance of its own functions as prima facie legitimate, and a matter to which courts would appropriately bend their understanding. As already suggested, the presumption reflects disrespect for a coordinate branch of government that is both hard to justify under other, well-established structural constitutional principles and redolent with potential political mischief; the same sorts of suppositions about human conduct applied to the courts produce at least equally distasteful outcomes. ${ }^{64}$ The argument appears also to be in the service of an approach to interpretation that fundamentally denies statutes' political moment. On this view, ideal interpretation is apolitical, and Heydon's fourth instruction does not appear

59. Id. at 941.

60. 484 U.S. 439 (1988).

61. Manning, supra note 1 , at 735 .

62. See id. at 735-37.

63. Id. at 737 .

64. See supra text accompanying notes $7,46-47$. 
to be an element of the judge's obligation. In Judge Hand's world, judges would be as careful to subordinate themselves to a fairly discerned political impulse (the lesson of the Progressive Era) as they would be to avoid the contrivances of particular members of the enacting body.

A decision from the last Term in the Supreme Court well illustrates respects in which I imagine Professor Manning and I would agree, and disagree, about the proper uses of legislative history. In United States $v$. Gonzales, respondents had been convicted in both state and federal courts of offenses growing out of a drug transaction in which firearms had been used. ${ }^{65}$ Both the state and the federal laws in question provided for the enhancement of criminal sentences if firearms were used; the federal statute provided that the additional sentence "[shall not] run concurrently with any other term of imprisonment," 66 and the state law contained a similar proposition. The respondents were first sentenced in state court, and the question then presented was whether the federal court was obliged to sentence the respondents to serve the $\S 924$ (c) portion of their sentence consecutively to the (enhanced) state sentence-whether "any other term of imprisonment" should be read as if it contained a qualifying "federal." One can identify a number of considerations adduced in the Court's several opinions, beyond the words of the text, as possibly bearing on this question. These considerations include: ${ }^{67}$

(1) The Senate Report accompanying the current language of $\S 924(\mathrm{c})$. It stated that " $\mathrm{t}] \mathrm{he}$ Committee intends that the mandatory sentence under the revised subsection 924(c) be served prior to the start of the sentence for the underlying or any other offense." 68

(2) The opening sentence of $\S 924(c)$, describing the offense of using a firearm in relation to drug trafficking crimes, which applies only to such a crime "for which he may be prosecuted in a court of the United States." ${ }^{9}$ But the prohibition of concurrency two sentences later, in the same subsection, does not repeat that qualifying language..$^{70}$

(3) Another amendment to $\S 924$ (c), enacted at the same time as the language being interpreted, that rejected a prior judicial narrowing of the section. Busic v. United States ${ }^{71}$ had held $\S 924$ (c) inapplicable to felony statutes that contained their own provisions enhancing punishment for firearm use; the new language made explicit that $\S 924(\mathrm{c})$ applied to all federal felonies, whether or not the statute defining

65. 117 S. Ct. 1032, 1034 (1997).

66. 18 U.S.C. $\$ 924(c)(1)$ (1994).

67. See 117 S. Ct. at $1032,1035-48$.

68. S. Rep. No. 98-225, at 313-14 (1983); reprinted in 1984 U.S.C.C.A.N. 3182, 3491-92.

69. 18 U.S.C. $\S 924(\mathrm{c})$.

70. See id.

71. 446 U.S. 398, 404 (1980). 
them also "provides for an enhanced punishment if committed by use of a deadly or dangerous weapon or device."72

(4) The general history of the statute (a revision of federal law) and its general context (sentencing provisions). These are concerned entirely with federal crimes; state law or state sentences are nowhere referred to.

(5) The absence of anything in the legislative history to suggest Congress was aware of or thinking about the impact of its action on state sentences. To enact legislation relating to state as well as federal sentences would be so unusual that one should expect something to have been said about it, if it was intended.

(6) Expanding the frame of reference from federal to state and federal crimes. Then the timing of state sentencing raises problems; a preexisting state sentence can be taken into account by the sentencing federal court, but if the federal sentence comes first, application of $\S 924$ (c) would depend on the state sentencing judge, to whom it does not directly speak.

(7) Finding the federal judge forced to impose a consecutive sentence for the identical aggravating factor that has already enhanced a state sentence. This possibility creates a harsh and possibly unconstitutional outcome that could not occur in a case involving only federal crimes-an outcome that cannot reasonably be ascribed to Congress.

(8) The only meaning ascribable to the phrase "any other term of imprisonment" is that it refers to state as well as federal terms of imprisonment, which leaves "no room to speculate about congressional intent. .. [ [I]t is not for courts to carve out statutory exceptions based on judicial perceptions of good sentencing policy." 73

The "Committee intends" sentence appearing in the Senate Report-the first of the items above-has no authority, and Professor Manning's argument gives us a useful way to think about why that should be so. The statement is unconnected with anything appearing in the enacted text of the statute; it addresses another problem entirely. Perhaps one could find in it evidence that its authors really meant "consecutive," or that their thought processes were limited to federal sentences, but the legal proposition it states is one that has not been enacted. Particularly where, as here, the issue concerns the remedy Congress has chosen-the third of Heydon's questions-the reasons for not giving it authority over the text are clear.

Yet an interpreter understanding the circumstances that produced that text may nonetheless fairly conclude that the text leaves unanswered certain questions about the mischief Congress was addressing. The Court

72. Id

73. See S. Rep. No. 98-225, at 313-14 (1983), reprinted in 1984 U.S.C.C.A.N. 3182, 3491-92. 
well knows that Congress often does not address issues, whether out of a failure to identify them, a failure of consensus, or the belief that others will be better placed to decide them. ${ }^{74}$ Here, the legislative text and materials, fairly read, convey two pieces of information about Congress's understanding of the mischief that it was addressing: first, that Congress was insistent upon sentence enhancement in the face of judicial qualms about double counting (the overruling of Busic); and second (including that suspect sentence from the Senate Report), that no one was thinking about the relation between this statute and state sentences when the passage in question came before the Congress. Nor is the linguistic situation quite as open and shut as the last of the items on the list above suggests. The topic sentence of paragraph 924(c) is limited to federal crimes. In everyday speaking and writing, certainly in everyday speaking and writing by a body as busy as Congress, "any other term of imprisonment" can easily be taken to refer back to the context thus established. To say that the language settles the matter is either pretense, or the infliction on Congress of a principle of care in drafting that it will be unable to meet.

The only body capable of resolving the lacuna thus identified is the Court. It is left in the position of choosing how to understand the affirmative legislative repudiation of its earlier approach of lenity, in light of its awareness that the state-federal issue has not been considered. Either outcome could be defended, but it ought to be defended on the ground of its probable better congruence with congressional purpose, rather than the assertion that it is the only choice offered by the text. ${ }^{75}$ The absence of any such discussion in Gonzales revealed it as a case for which Congress had not provided. Thus, the courts would be setting sentencing policy however they decided the matter. Judicial reference to the legislative history for these purposes would say nothing about the authority of committee staff; rather, it would both inform the judicial lawmaker about the mischief Congress had or had not addressed and embody important propositions about the courts' relation to Congress.

74. See Chevron, U.S.A., Inc. v. Natural Resources Defense Council, Inc. 467 U.S. 837, 866 (1984).

75. Formally, the Court would be making the law on this matter even if some members of Congress had debated using the word "federal" as part of that phrase but the legislature had not done so. If the historical record showed that members had identified the issue, the word's absence would provide the basis for an argument that this problem had been considered and arguably resolved. But, for all the reasons Professor Manning suggests, that history would not bind the courts, which would remain free to read "any" as "any federal," even had an amendment to insert "federal" been offered and defeated. Congress could itself fill the lacuna only by enacting one of two verbal formulas, "federal" or "federal or state," after "any." 


\section{B. Interbranch Respect and Coordination}

To deny the propriety of this kind of inquiry, or the attitude toward the judicial-legislative relationship it suggests, ${ }^{76}$ is to impose just those sorts of burdens on the legislative process that Lieber identified. ${ }^{77}$ Recognizing the problem, Professor Manning suggests two reassuring responses: first, that "textualism is not about the level of legislative detail; it is about where the detail appears"; 78 and second, that eliminating legislative history may increase the flexibility of statutes, by freeing future interpretations of artificial (and resource-costly) constraint. ${ }^{79}$ Yet any reassurance we might take from these observations wholly depends on our confidence in the interpreters as faithful agents-and that returns us to the disturbing subtext of the proposition, in a postmodern age of textual indeterminacy, that courts should hold themselves free of any knowledge of the political history of statutes or the problems their enactors expected them to deal with. Why should we, their principals, wish to tolerate courts as mere manipulators of enacted verbal formulae who cleverly employ a sharply limited palette? Why should we wish the Congresses that we elect to enact statutes as best they can, in response to such problems as appear actually to have arisen in public life, to have to plan for courts who read according to their own principles of grammar and interpretation, uninformed by political history-in-fact? Enacting Congresses required to understand that they are dealing with interpreters indifferent to the problems they actually foresaw, save as may be reflected in the text they announce, can be expected to mirror the British Parliament's behavior $^{80}$ - and of course, both human language and human foresight being imperfect, they will fail. Enacting Congresses understanding that flexible words would be interpreted by unaccountable interpreters, without regard for the political history that generated them, would be irresponsible to enact the flexibility Professor Manning properly hopes for. That behavior, we can anticipate only of those who are somewhat trusting of the good will with which their words will be understood.

Indeed, perhaps the most important proposition on the table, one that tends to be obscured by Professor Manning's analysis, but that is strongly entailed by the writings of those judges whose approach he seems most to admire, concerns the political differences between purposive and formal interpretation. ${ }^{81}$ The stance of being guided by congres-

76. As Judge Posner put it, dissenting in United States v. Marshall, 908 F.2d 1312, 1338 (7th Cir. 1990), aff'd sub nom. Chapman v. United States, 500 U.S. 453 (1991), "We should not make Congress's handiwork an embarrassment to the members of Congress and to us."

77. See supra text accompanying note 5 .

78. Manning, supra note 1 , at 729 .

79. See id. at 730 .

80. See supra note 5 .

81. See Peter L. Strauss, On Resegregating the Worlds of Statute and Common Law, 1994 Sup. Ct. Rev. 429, 527-40. 
sional purpose is one of commitment to the enterprise of government; that of textualism, as its judicial proponents have expressed it, one of neutrality and refusal of responsibility. Here, we approach the fourth Heydon's Case proposition: once one has determined the right construction of the statute, by whatever means, it is the judicial obligation "to add force and life to the cure and remedy," 82 in support of the congressional action. The proposition that the judicial role in relation to statutes ought to be a supportive, cooperative one creates no issue about congressional self-delegations. On this understanding, the greater legitimacy of legislative lawmaking in competition with judicial lawmaking puts the federal judiciary under an obligation to integrate Congress's dispositions generally into judicially articulated law. A delegation-based concern with the use of legislative history has, in itself, no implications for that proposition.

This normative proposition found expression in the American literature as early as 1908, when Roscoe Pound-writing in reaction to the formalism of the preceding years and in support of the growing recognition in progressive judicial circles of the importance of legislative innovation-supposed four postures courts might take towards statutes:

(1) They might receive it fully into the body of the law as affording not only a rule to be applied but a principle from which to reason, and hold it as a later and more direct expression of the general will, of superior authority to judge-made rules on the same general subject; and so reason from it by analogy in preference to them. (2) They might receive it fully into the body of the law to be reasoned from by analogy the same as any other rule of law, regarding it, however, as of equal or coordinate authority in this respect with judge-made rules upon the same general subject. (3) They might refuse to receive it fully into the body of the law and give effect to it directly only; refusing to reason from it by analogy but giving it, nevertheless, a liberal interpretation to cover the whole field it was intended to cover. (4) They might not only refuse to reason from it by analogy and apply it directly only, but also give to it a strict and narrow interpretation, holding it down rigidly to those cases which it covers expressly. ${ }^{83}$

At the time, he was hopeful that American courts were moving from the fourth "orthodox common law attitude" to the third posture; one day, he hoped, we would see the second and then the first as most appropriate to an age of statutes. ${ }^{84}$ Strikingly, the contemporary judges who most forcefully express the constitutional inhibitions on the use of legislative history Professor Manning invokes, seem also to adopt Pound's fourth mode of judicial relationship to statutes, holding them rigidly to those cases expressly covered. ${ }^{85}$ Their explanation is not that against which Pound re-

82. See supra text accompanying note 56 .

83. Roscoe Pound, Common Law and Legislation, 21 Harv. L. Rev. 383, 385 (1908).

84. See id. at $385-86$.

85. See, e.g., Frank H. Easterbrook, Statutes' Domains, 50 U. Chi. L. Rev. 533 (1983). 
acted, the canon that statutes in derogation of the common law (i.e., judicially generated legal authority) are to be narrowly construed. Rather, they say, it is only for Congress, not the courts, to make law. ${ }^{86}$ Or, perhaps, they evoke the public choice view that as the product of private deals, statutes should be given no broader reach than the deal made. ${ }^{87}$ The posture is in sharp contrast with the normative commitment of the fourth inquiry in Heydon's Case, that judges have an obligation to cooperate with the legislative impulse by using their common-law powers to propagate its force.

If there is a constitutional argument in this contemporary judicial posture, it is a different one from Professor Manning's delegation argument, and it is an argument distinctly hostile to the legislative enterprise. As Professor Merrill noted in the passage earlier quoted, ${ }^{88}$ this argument abstracts the judge from her position as part of government-denying, against more than two centuries of experience, that judges share with Congress responsibility for lawmaking. The argument comes close to putting into the Constitution-from which only an amendment could remove it-a choice for Libertarian minimalist government; that proposition seems no more defensible than the claim that Herbert Spencer's Social Statics lives there. ${ }^{89}$ The proposition that the drafters of the Constitution opted for a deliberate legislative process, likely to withstand momentary populist surges, hardly entails minimalist government enforceable by judges who could avert their faces from the larger sweeps of change and require the Congress to do its work again and again. The Constitution embodies no presumption against interpreting laws that have once passed through the demanding congressional process in a manner that will "suppress the mischief, and advance the remedy."

\section{Purposivism as a Nonaggrandizement Doctrine}

Finally, Heydon's Case-both the inquiry it defines as a whole, and the normative commitment embodied in its fourth element-assumes what might be controversial, that legislation is purposive behavior. At times Professor Manning's argument appears to be that the insights of public choice theory preclude our taking that view. ${ }^{90}$ Putting aside whether the respect constitutionally owing by each branch for the behaviors of the others even permits embracing that sort of view (surely not held by the framers) as if it were constitutionally compelled, one immediately understands that analytic sauce for the goose must also be ladled on the gan-

86. NLRB v. Health Care \& Retirement Corp. of America, 511 U.S. 571, 580 (1994); See Central Bank v. First Interstate Bank, 511 U.S. 164, 173-178 (1994); Strauss, supra note 81 , at 509-16.

87. See Easterbrook, supra note 85 , at 544-51.

88. See supra text accompanying note 48 .

89. See Lochner v. New York, 198 U.S. 45, 75 (1905) (Holmes, J., dissenting); Eskridge, supra note 16, at 408 .

90. See, e.g., Manning, supra note 1, at 684-89. 
der. Judges equally with legislators must be understood to have personal agendas, to act in pursuit of maximization of their own self-interest, etc. It cannot do to suppose that they uniquely act in a neutral, public-spirited way. From the perspectives both of the Constitution and of public choice, judges are no less our agents as government officials than legislators are; consequently, how their fidelity to their principals (the people) can be assured is no less a question than it is for legislators. What thoughtful principal would authorize use of an interpretive convention permitting (if not commanding) one of its agents to regard the work of another agent (i.e., the legislature) with disdain? Indeed, since for other (good and sufficient) reasons we keep the courts particularly free from the possibility of ordinary discipline, while the legislature is more often and much more closely controlled, our taking such a hazard is inconceivable. Regrettably, as our previous fin de siecle history already taught, that consideration will not necessarily keep the judges from attempting to seize that power for themselves, in the service of their own personal agendas.

Seeing this helps understand that the Heydon's Case assumption, mirrored in the later Legal Process materials of Hart and Sacks, ${ }^{91}$ is not a descriptive statement about legislatures, subject to what has always been trivial disproof. ${ }^{92}$ When Professors Hart and Sacks wrote that it was the obligation of judges to presume that legislation is "the work of reasonable men pursuing reasonable purposes reasonably, unless the contrary is made unmistakably to appear," ${ }^{93}$ one could hardly suppose they thought they were describing an actual state of legislative affairs. Legislatures are no more likely or required to act reasonably in fact than jurors are. The issue at hand was describing, not how legislatures are, but the right relationship of judges to legislative work. The Hart and Sacks adjuration echoes the restraints judges regularly observe in relation to the reasonable man, juror, and agency. ${ }^{94}$ It translates into the legislative context the normative attitudes to which we hope courts will adhere in all adjudication: that it is the product of reason and reasoning and that the judge is

91. See Hart and Sacks, supra note 19, at 1125.

92. Otto Von Bismark is generally credited with the observation that, for legislation as for sausages, one should enjoy the result, but not watch the making. See, e.g., Community Nutrition Inst. v. Block, 749 F.2d 50, 51 (D.C. Cir. 1984). Whether he made the statement or not, few doubt its accuracy.

93. Hart and Sacks, supra note 19, at 1125 .

94. In a variety of contexts, judges employ propositions about what would be "reasonable" (as distinct from ideal) behavior as a means of subduing their own preferences about outcomes. They identify not the right outcome, but a range of outcomes that would be reasonable, as contrasted with others that would not. The behavior of a "reasonable man" engenders no liability even if the judge would not have behaved that way. A finding that might have been made by a reasonable juror must be accepted even if the judge would not herself have made that finding. An agency's "reasonable" choice of statutory interpretation, on an ambiguous matter within its responsibilities, must be accepted even if the court, reasoning ab initio, might have reached a different result. 
obliged to make the effort to subordinate her own preferences to those of the larger community as reflected in existing law. She is to seek as Justice Stone once put it, "the ideal of a unified system of judge-made and statute law woven into a seamless whole by the processes of adjudication." 95 Courts should regard the work of legislatures as embodying purposes it is their responsibility to advance, so as to "add force to the cure and remedy," not because it necessarily is purposive, but because their doing so is a useful safeguard against judicial aggrandizement, as well as against running battles between Congress and the judiciary over nonconstitutional policy judgments that could again-as they have in the past-prove destructive to the general effectiveness of government. Against these agents, whom we cannot vote out of office when they resist the work of those we vote in, that socialized attitude is about all the protection we their principals have. And when they abandon that attitude, or when we find ourselves facing arguments that encourage if not command them to do so, we ought properly to be concerned.

\section{CONCLUSION}

Professor Manning appears to agree with the principal impulse of this Essay, that saying the courts are forbidden to look at legislative history is an error of equal magnitude to saying they are bound by it. Our difference is perhaps one of emphasis. Considering the courts, too, as political institutions whose misuse of authority must somehow be kept in check, in my judgment, requires judicial acknowledgment of a partnership with the Congress. That acknowledged partnership must be one that respects the general integrity of its processes (while mindful of the possibilities of manipulation). It must accept that the Constitution, like Heydon's Case, requires of it the attempt to discern and build upon the public, political impulse of legislation. In such a context, the political history of legislation cannot be a suspect inquiry. Even in doubting the coherence of the inquiry, we would have to remember as well its importance as discipline for the inquirer; for the same insights that might make us doubt the existence in reality of a public-regarding legislative purpose must also make us extremely chary of judges who declare their independence of any inquiry into political history. For the reasons Professor Manning elegantly evokes, the courts should not accord legal authority to individual elements of that history; but an intelligent, independent, and respectful examination of it need reflect neither judicial subservience nor, what would be as objectionable, judicial disdain.

95. Harlan Fiske Stone, The Common Law in the United States, 50 Harv. L. Rev. 4, 12 (1936). 